\title{
接點皮膜の接觸抵抗につ、て
}

\author{
高木通 泰* 三 戶隢*
}

Michiyasu Takagi and Satoru Mito: On the Contact Resistance of the Film on Electric Contacts. In this paper some results obtained from the experiments on the contact resistance of the films formed by discharge on $\mathrm{Ag}, \mathrm{W}, \mathrm{Cu}$ and other several alloy contacts are given. The contact resistance was measured closely point by point, with a $\mathrm{Ag}$ neecile mounted on a special measuring apparatus.

The results obtained are as follows:

(1) On the anode surface, some cathode material is transferred and the distribution of contact resistance shows a complicated structure.

(2) On the cathode surface a new heat resisting surface is formed by discharge, and, consequently, the contact resistance of the cathode is very low.

(3) On heating, the contact resistance of $\mathrm{Ag}$ and $\mathrm{Cd}$ against the $\mathrm{Ag}$ needle decreases, while that of $\mathrm{W}^{\cdot}, \mathrm{Cu}$ and others increases.

(4) In the case of alloy contacts, these films are composed of oxides of the alloying elements.

(Received October 28, 1950)

\section{I. 絡氞}

一般に接觸抵抗の問題は電氣接默に跨いてかなり重要な 問題である.これに関しては從來主として賔際的立場か ら，相當時間作動後の接唯について测定したものが多く，

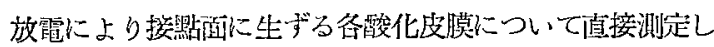

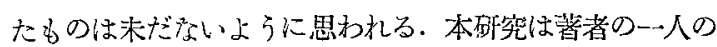

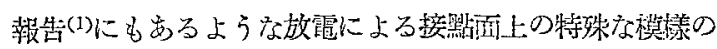
酸化皮膜について微動裴置に上り各場彪每の淁解抵抗它测 定し以つて接觸抵抗並びに接點現象の解明の一助たらしめ んとしたものである.

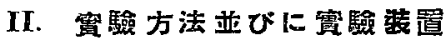

實驗の方法としては各試料板に放電により皮荧を生成せ しめ,これに Ag 針を接臅せしめて微小雷流を流しこの ときの電壓をミリボルトメーターで临み，これから皮膜の

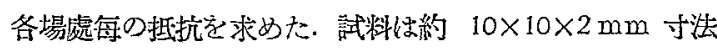
の板でこの機械研磨後の声漂面について他極を針として放 電を行わせた。放電の條件は最子明瞭な皮膜が得られる籁 園として D.C 35V 2A を選んだ. Fig. 1 は實驗裝置を

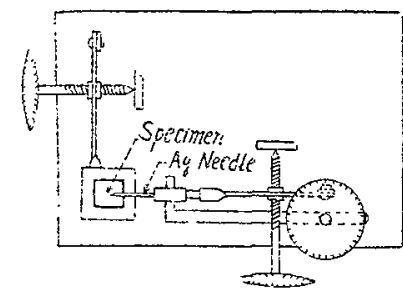

Fig. 1 Measuring Apparatus. 示す.圖涀るよ 引に試料台及び Ag 剑はネジの部 分により微動せし められ，試料面の 任意の場處につい て测定することが 出來る. また接䚡 壁功同じくバネ

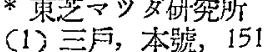

板により加減されしれは $500 \mathrm{mg}$ とした．测定は大體 $50 \mu$ 每に行つたが，測定後值ちに檢鏡して Ag 針による

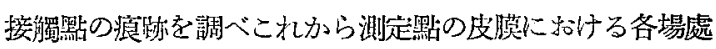
を判定し，㳄にかつるもの劣時種々なる溫度に熱處理し てその初回の测定點に近い、䵪につき前同榡の测定を行つて

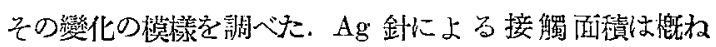

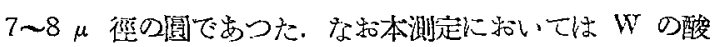
化皮膜には明らかに整流性が認女ら扎たか， Ag，Cu 等に ついては認められなかつたので整流性の間題は別に考慮す ることにして筫驗莨行つた.

\section{III. 宽駔 結 果}

實驗はまず $\mathrm{Ag}, \mathrm{W}, \mathrm{Cu}$ について爾極同程の場合及び異

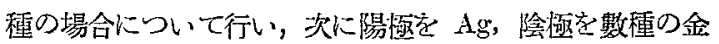
閩及び合金とした場合のそれぞれの影響につき調べた。

\section{Ag 接 默}

(a) $\mathrm{Ag}$ 陽極對 $\mathrm{Ag}$ 陰極 一船に $\mathrm{Ag}$ の場合に限らず 單一放電によつて陽㥛面に生ずる酸化皮腅は顛微鏡で見る と縞狀の干涉模㨾を是するが，な衫付細灌察するとこの 中には不連續的に色の變化する部分があり，必ずしも單純 ではい，接䚪抵抗を测定した場合もこの色の不連續的に

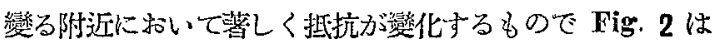
その一例定示寸。圆は直徑約 $4 \mathrm{~mm}$ の $\mathrm{Ag}$ 针を除極とし て放電させた場合の $\mathrm{Ag}$ 陽㥛面上の皮膜の各場處に和け る抵抗測定値であり，縱軸は接触抵抗侹，横軸蜼は皮膜の場 发をを示す．圖に示寸上5に中央附近に扒いて担抗値の極大 及び極小が見られ，中央部附近の抵抗が最も高い，Ag の 酸化物は比皎的低溫に叔いて分解寸ることが知られ、ている

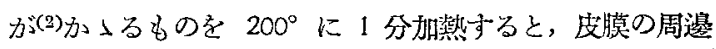

(2) J. W. Mellor, A Comprehensive Treaties on Inorganic and Theoretical Chem., Vol. III (1928), 371 . 
部附近に物いては酸化が更に進行するためか担抗が叠加し てくるが中央附近では酸化物の分解力咍台るため抵抗は

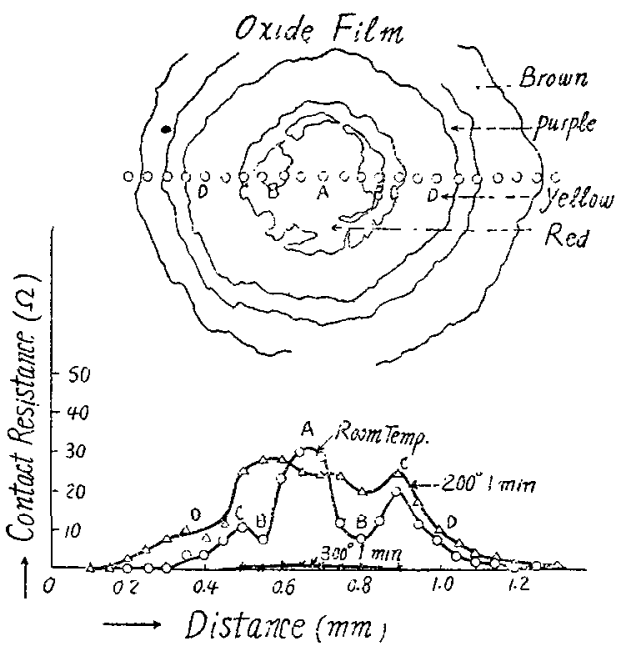

Fig. 2 Contact Resistance of the Ag Oxide Film Formed on a Ag Anode Surface.

低トし，更に $300^{\circ} に 1$ 分加熱与るといつれ部分も圣 く低下寸る，㴔微鏡的にもこの溫度では皮膜の消失か認め

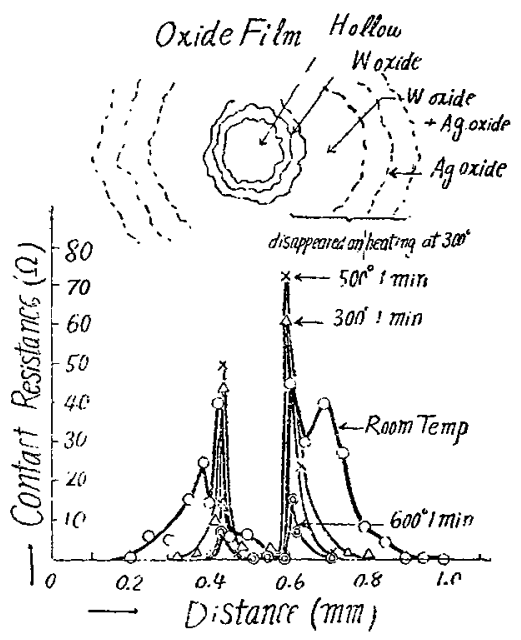

Fig. 3 Contact Resistance of the Oxide Film Formed on a Ag Anode Surface by a W Cathode Point.

られる.この際嗔味あることはか」るもの更に $400^{\circ} に$ 1 分加熱寸ると，消失した皮膜の外侧にこれから約 0.1 mm 隔て小茶色の摆狀の部分が新しく現われるのが鹳察 され，し加出この際この茶色の環狀の部分と皮膜の专つた 部分は金屬光濢を呈して更に温度を上げてもこの部分のみ

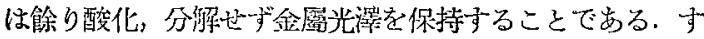
なわちこ狄は後にも述べるように放留によつて實際に皮膜

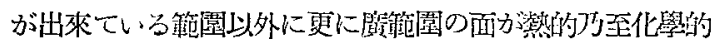
の何らかの影留定受けて變化していることを示すもので，

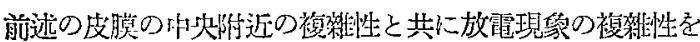

示すむのである.

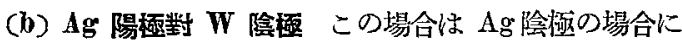
比して，中央部附近の抵抗は著しく高く，しか３ $300^{\circ}$ 以 上の加熱に際してもこの部分の皮膜の夕は消失せず担抗は 增加する.W の酸化皮膜は 後述するように加熱によつて 抵抗を堌加寸るるのであり，こ机らのことから中央部附近 の皮膜は W の酸化皮膜ですること方湖られる. Fig.3は

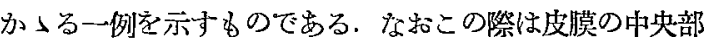
が一部熔融して究狀となり $\mathrm{Ag}$ 面沙現われているためその 部分の拎抗値は低くなつている。

(c) $\mathrm{Ag}$ 陽㥛對 $\mathrm{Cn}$ 陰極 $\mathrm{Ag}$ 陽極の皮膜上には $\mathrm{Cu}$ の 酸化物加附着生成し担抗健は高い。この場合は $W$ 陰極の 場合に比し Cu の酸化物が此较的筫範周園の面に形成される

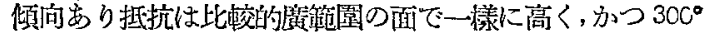
以上の加熱心際しても皮膜の消失する部分は少い. $600^{\circ}$ 附

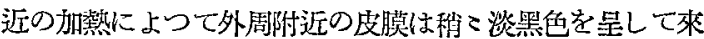

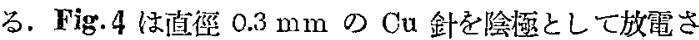

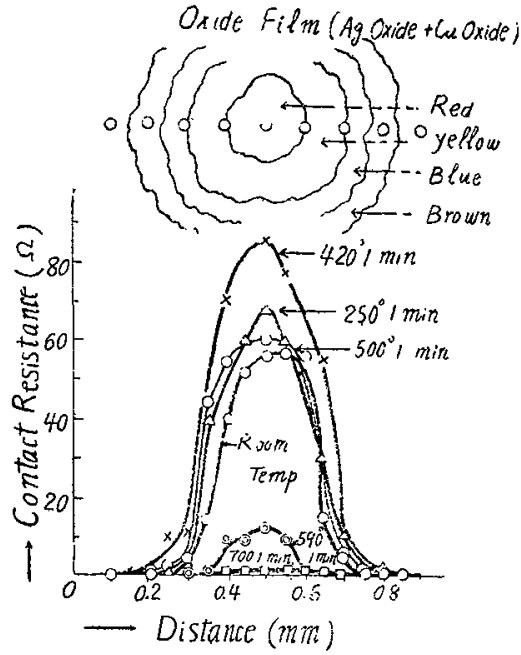

Fig. 4 Contact Resistance of the Oxide Film Formed on a $\mathrm{Ag}$ Anode Surface by a Cu Cathode Point.

せた場合の一例である。

以上 (a)(b) (c) に㟧いて述べたことからもわかるよう

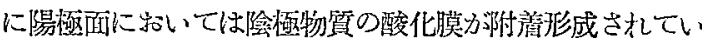

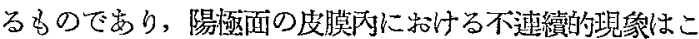
の除極物質酸化膜の附着形成に基くものである.

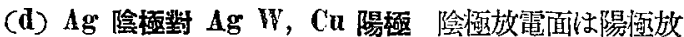

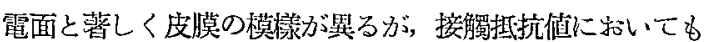
著しい相照が認められいるす寸字わち中央の皮膜の飛散した

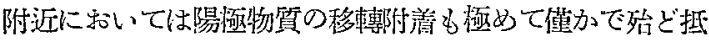
抗々認められず，たが放電の外周部に殘存する皮膜の部 分に若干の担抗力認められるだけであり，これはは陽㥛物質 の種䞆儿無関係である。

\section{W 揬 點}

(a) W の常溫酸化皮膜 W は常溫に和いて著しく酸化 
するものでこれは霆マ接點の㜔碍となるすのである.

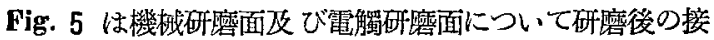

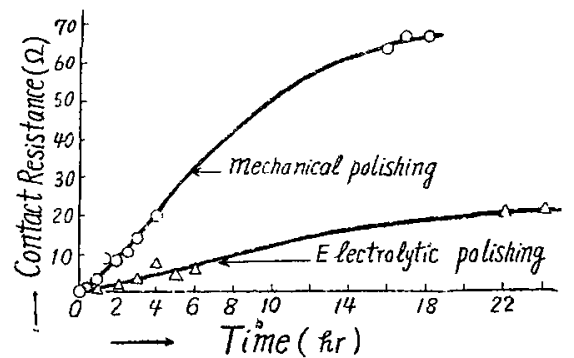

Fig.5 Time Dependence of the Contact Resistance of a W Surface.

觸抵抗值の時間的變化を測定したるので，圖に示すように 外觀的には鏡面を呈する姢態に物いて毁にかなり酸化し， かつ機械研踣面は電解研磨面に比乙その酸化速度は 4,5 倍程度高い。

(b) $W$ 陽娽対 $W$ 隍極 前項に扎いて述べたようにW は常溫で著しく酸化するために测定は研磨後迅速に行5必 要があつた，Fig.6 は雨極とも!W の場合であり，圆に見

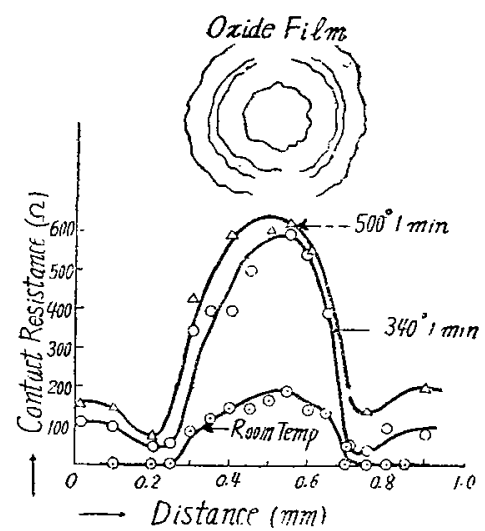

Fig.6 Contact Resistance of the Oxide Film Formed on a $W$ Anode Snrface.

るように放電による酸化皮膜の抵抗は加熱によつて更に增 加し，乙かる加熱に際しては皮膜の存在しない部分にも担 抗値の一つの變化力現われて來るものて，これは Ag 接 點の項において述べたような皮膜は存在しないか湤電によ るなんらかの影響を受けて變化している部分であり，圖比 見るように耐酸化性の面となつている．これらのことは次 の $\mathrm{Ag}, \mathrm{Cu}$ 陰極の場合により明膫に認められる。

(c) W 陽趢対 Ag 隆極 Fig.7 は機战研磨後 17 時間 經過し常㴧に括いて約 $50 \Omega$ 程度の接解抵抗健を示す $W$ 面について Ag を陰極として放電させた場合の例で，圖

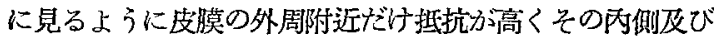
外側の皮荧の生成してない所は抵抗は低い。これは內側の 部分は $A g$ の酸化膜か形成されてるためであるが，皮膜の 外侧の部分は放電前に存在していた酸化愿方放電に際して

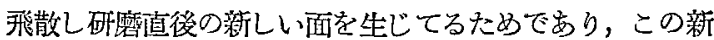

しく生じな面は前述のように加熱に際しても抵抗は增加し にくい面でする. $340^{\circ} 1$ 分間の加熱では中央部は $\mathrm{Ag}$ の

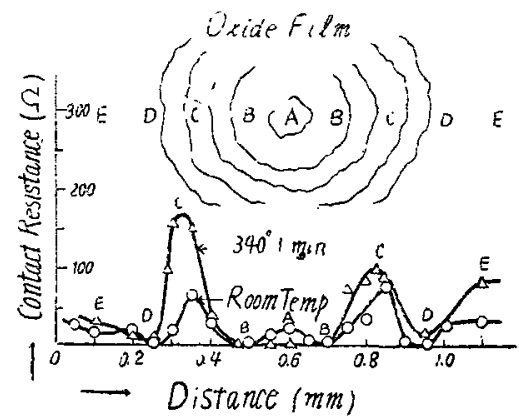

Fig. 7 Contact Resistance of the Oxide Film Formed on a $W$ Anode Surface by a Ag Cathode Point.

酸化物分妢解するため 担抗は低下し $0.1 \Omega$ 程度になるが W 皮膜の存在与る外周部附近は却つて抵抗は增加し $100 \Omega$ 以上となる。

(d) W 陽極対 Cu 阮極 Fig. 8 は前同樣, 研磨後 17 時間經過した面について Cu除極で放電させた場合の例て

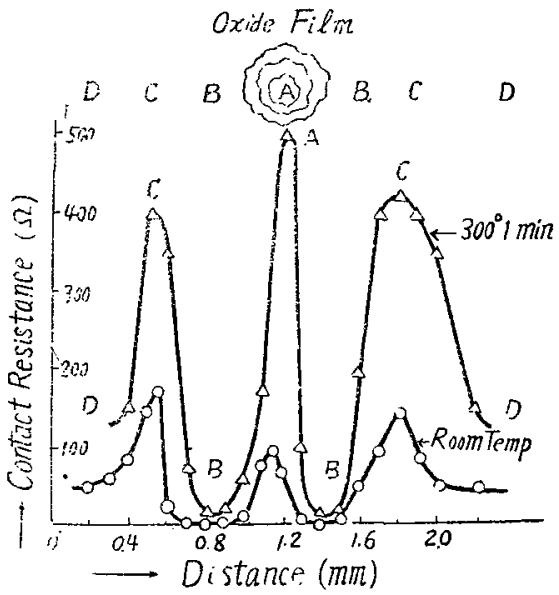

Fig. 8 Contact Resistance of the Oxide Film Formed on a W Anode Surface by a Cu Cathode Point.

ある．圖に見るように皮膜部以外の構造も明膫に示されて いる. A は皮膜部，B は前述の上うな酸化層の消失して 新しい面が出來てる部分， $\mathrm{C}$ は $\mathrm{Ag}$ 接點に特いて述べた ような加篎際して新しく茶色の縞力現われる部分ですな わら酸化し易くなつている部分でする。

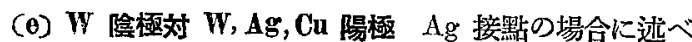
たように，阷極面の抵抗は陽極の種類の如何に拘わらず常 に著しく低い. Fig.9 は研磦後 17 時間經過の面について 放電させて得られを $W$ 陰極面についての測定絈果です る. 圆に示すように陰極面に执いては放電によつて廣い範

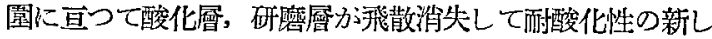
い面が生ずるものである

\section{Cu 接 䓡}


$A g$ 接點，W 接點の場合と全く同樣の傾向を示し，す なわ告陽極皮膜の中央には除極物質力㳱着してそ礼ぞれの

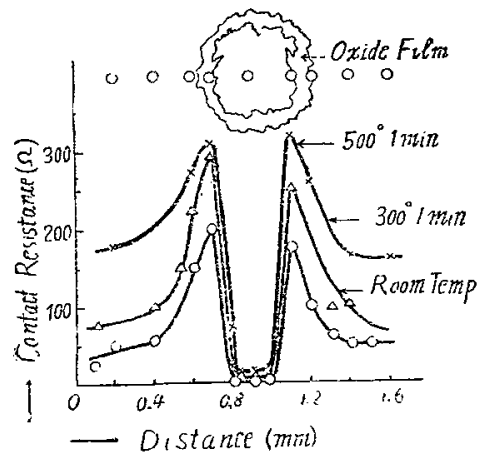

Fig. 9 Contact Resistance of a $\mathrm{W}$ Cathode Surface Discharged by a W Anode Point.

抵抗値を示し，陰極面におる。ては耐酸化性の面吕現われて 抵抗値は極めて低い。

\section{4. 合 金 接 點}

以上 $1,2,3 ， に$ 就いて述べた諸結果から制るように，陽 極放電面には陰極物質が移轉附着しているものであるが， 陰極に合金孛使用した場合各合金元素の影響如妸に現わ れるかを次に述べる。

\section{(a) $\mathbf{A g}-\mathbf{W}$ 合 金 隊 極}

Fig. 10 は $\mathrm{Ag} 80, \mathrm{~W} 20$ の Ag-W 䛈絓合金を陰極と した場合の $A g$ 陽極上の皮膜の抵抗値を示するので, 圖に 示すよらにその皮膜には $\mathrm{Ag}, \mathrm{W}$ の影響が共に現われその

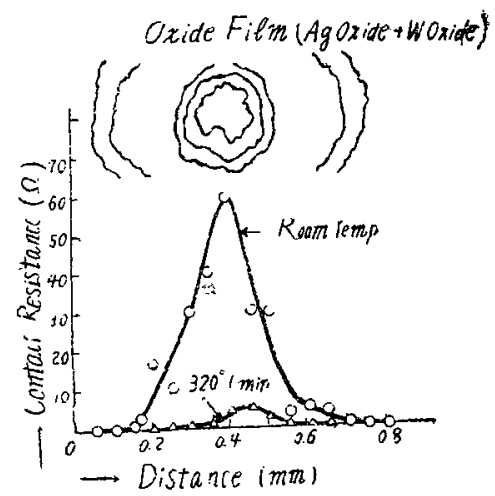

Fig. 10 Contact Resistance of the Oxide Film Formed on a Ag Anode by an Elconite ( $\mathrm{Ag} 80 \%$, W 20\%) Cathode Point.

抵抗値はW ザけの場合上り低く Ag だけの場合よりは售

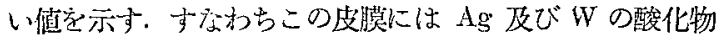
が共序していると考穴られる。然るにからるもの加熱す るとAgの影響方浣和れて坻抗は何えの部分も低下して 來る。

\section{(b) $\mathrm{Ag}-\mathrm{Cu}$ 合金阷 極}

洪晶合金の場合の一例として $\mathrm{Ag}-\mathrm{Cu}$ 合金险植の例定 Fig. 11 に示寸。圖に示寸上うに Agに Cuが入ると担抗
は共晶附近记は Ag だけの場合と㱛ど變らないがこれ以 上になると次第に $\mathrm{Cu}$ の影響が現われて担抗は富くなる。

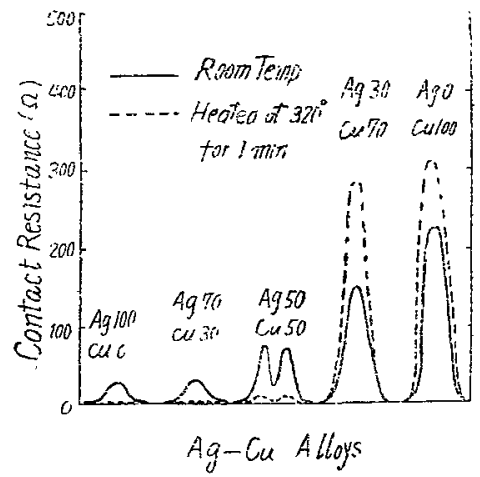

Fig. 11 Contact Resistance of Various Oxide Films Formed on a Ag. Anode Surface bo Ag-Cu Alloy Cathode Points.

加熱に際して子共晶附近迄のるのは $A g$ の酸化物の分解 の影響を受けて抵抗は低下寸るが，これ以上になると $\mathrm{Cu}$ の酸化物の影響を受けて次第に習加して來る，この中特に 與味あるのは Ag 50，Cu 50 の組成のものでこの際は圖に 見るよ弓に中央に $\mathrm{Ag}$ の酸化物が集り外周部に $\mathrm{Cu}$ の酸 化物が集まつているように見られることで，こ机陽叒 に䔟轉附着する際に $\mathrm{Cu}$ が Ag に比し 遠方迄飛散するた

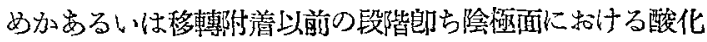
皮膜の形成に際して Cu の方方 $\mathrm{Ag}$ より山酸化し易いた めに皮膜の外周部には主として Ou の酸化皮膜の夕が形成

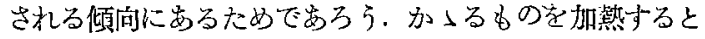
何礼の部分子抵抗は低下して來る。Ｏ叭酸化物は元來加 熱によつて担抗は墰加すべきものである故この際も外周部 の抵捖は却つて堌加すべきであるに拘からず，前項の $\mathrm{Ag}$ $\mathrm{W}$ 酸化物の湿相に拁ける この部分の抵抗値は低下して來るものである。なおこの際 は接觸抵抗測定時の接蠋面積は他の場合上り稍ミ小で約 $(2.5)^{2} \pi \mu^{2}$ であつた.

(c) その他 前述の $\mathrm{Ag} \cdot \mathrm{Cu}$ 共晶合金との比较の意味で 固溶體合金として On-Zn 合金について行つたが蜍り明膫 な結果は得られなかつたまた微量元素の影響を見るため に $\mathrm{C}$ 量 0.1 及び $0.7 \%$ 鋼について行つた結果では雨者

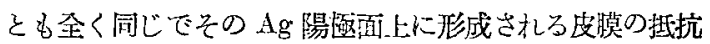
は放電を後で $175 \Omega$ 程度， $1320^{\circ} 1$ 分加熱で約 $470 \Omega$ で あつた。

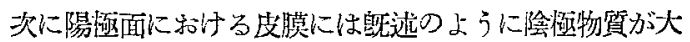

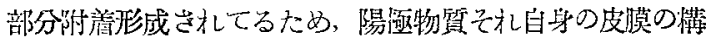
选にむつては餘り明䐲でないため踼㥛を合金とした場合の

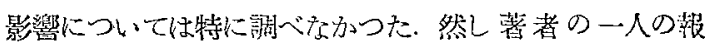

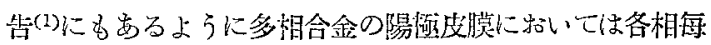
に皮膜が形成されるる傾间にあり，從つて例完ば前述のA

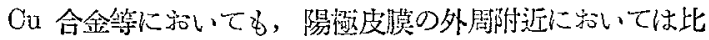
較的酸化さ机易いCuの影響が主として現加れること思 
わ叔る。

\section{5.その他苦干の金属接黙}

その他 $\mathrm{Ag}$ を陽極として $\mathrm{Ni}, \mathrm{Al}, \mathrm{Pb}, \mathrm{Sn}, \mathrm{Zn}, \mathrm{Cd}$ 及び Os $10 \%$ Pt-Os 合金等を陰極としてそ狄らの皮膜につ いて調べたが $\mathrm{Al}, \mathrm{Pb}, \mathrm{Sn}, \mathrm{Zn}$ 等恰その皮膜の接觸抵抗値 は著しく高くこれらは接點として問題になら奴上らに思わ れた. $\mathrm{Ni}$ の場合は常溫の接觸抵抗值は約 $40 \Omega 320^{\circ} 1$ 分 加熱では $75 \Omega$ 程度であつた。 また $\mathrm{Cd}$ の場合は $\mathrm{Ag} の$

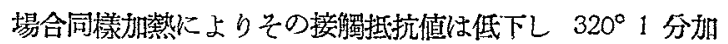
熱で $60 \Omega$ より約 $6 \Omega$ 迄低下した. かくの如く加熱によ りその接觸抵抗值の低下寸する見橡は實際接點として起で有 利なことであると思われる。Os 合金では加熱前に物いてて からる皮膜は大部分消失していぞ

\section{IV. 䑩 嘼}

以上放電に上る陽陰兩極面上の種々なる皮膜についてそ の接能蜀抵抗を澌定した結果学述べたのであるが，これらを 簡單に總括すると次の如くで岁る。

(1) 陽極放電面上に址ずる皮膜は陽浭物質の酸化物の他

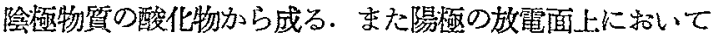

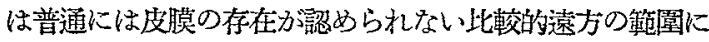
招いても，放電水よる酸化皮膜の形成されていることが加 熱後の测定から槯加められた。

(2) 陰極面には放電に上り新しい耐酸化性の面が坐じ， 從つて陰極面の接觸抵抗は極めて低い。

(3) 放電による酸化皮膜には Ag， Od の皮膜のよ5に 加熱により分解してその接解抵抗の低下寸るものと，W， $\mathrm{Cu}$ その他の上引に加等北より酸化方淮及接觸担抗の增加 するものがある。またこの兩者が共存するような場合，一 方の影響を强く受けて例光ば本來加熱に上つて抵抗の墂加 すべきものも却つて低下して來る現翮がある。

(4) 合金接點の皮膜にはそれぞれの合金元素の合成效果 が現わ机る。

(5) W は常溫に物いて極めて酸化し易いが電解研磨面

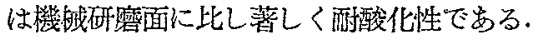

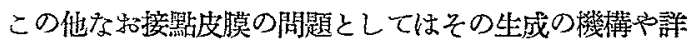
細な構造の問題, また吸着等の化學的性質, 整流性の問題 など解決すべき點が多い，これらは今後に残さ扎た開題で める. 